Seymour, J. S. Willman, Mrs. Bridie O. Wilson, Margaret Wood.

1Awarded honours. 2Distinction in obstetrics and

BRISTOL

Appointments.-Dr. P. N. Dixon (lecturer in public health); Dr. A. Edwards (demonstrator in patholog).

WALES

Welsh National School of Medicine Appointments.-Dr. B. H. Knight (senior lecturer in forensic pathology, Department of Pathology) Dr. Eileen $N$. $M$ Anderton (lecturer in anaes thetics); Dr. M. R. Beamish (lecturer in haematology, Department of Pathology); Dr. T. M. Hayes (lecturer in gastroenterology).

\section{ROYAL COLLEGE OF SURGEONS OP ENGLAND}

At a quarterly meeting of the Council held on 11 July with Sir Hedley Atkins, president, in the for the ensuing year. Mr. H. C. Edwards was re-elected and Sir Thomas Holmes Sellors elected vice-presidents for the ensuing year.

Mr. R. Cox (Westminster Hospital), Mr. D. M. Morrissey (Birmingham), and Professor F. E. Stock (Liverpool) were re-elected, and Professor A. J. Harding Rains (Charing Cross Hospital), Mr. N. E. Stidolph (Whittington Hospital), Mr. J. S. H. Wade (Cardiff), and Mr. L. F. W. Salmon (Guy's Hospital) were elected to the Court of Examiners for the ensuing three years.

Hallett Prizes were awarded to Dr. G. B. Coombes (Charing Cross Hospital Medical School) and to Dr. W. E. R. Green (The London Hospital Medical College).

The award of the Nuffield Prize (Faculty of Anaesthetists) to Dr. N. R. Fahmy (Cairo) was recorded.

The following diplomas were granted, jointly with the Royal College of Physicians of London :

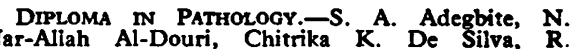
gynaecology. Distinction in paediatrics.
ion medicine. chair, Sir Hedley Atkins was re-elected president

Devarajalu, E. Doe-Doosey, A. P. Dorevitch, P. B. Hamal, A. A. Jaffe, Kusum L. Marwaha,

Diploma in ANAESthetics.-Doreen L. Aitken M. D. Allam, M. A. B. Allan, A. H. Ansari, S. K. Bagchi, P. W. Bailey, Barbara A. Baird, Ruby K. Baksh, P H. Balkrishnan, T. M. Ball, Fich K. B. J. Beswick, Pamela Booker, Jacqueline Y Bottome, Ann R. Bowdler, Anne G. Boyle, beth Calder, Joy S. Catling, Chiu-Suck Chan, S. C. beth Calder, Joy S. Catling, Chiu-Suck Chan, S. C Chishti, M. A. Choksi, Hazel G. Chung, Jane T Conner, C. C. Das, R. J. L. Davis, Maria P. Demetriou, L. G. Dempsey, Flora M. McK. Engler, $\dot{K} . \mathcal{S}_{\text {S. Erel, J. Evans, J. C. D. Ferreira, }}$ Ruth M. B. Furness, Margaret M. Gibbon, J. D. Hanna, P. L. Harrison, N. Hasan, R. Hassan, D. M. Hastings, A. M. Hipkin, Anne D. Hodson D. M. Jackson, B. James, S. Jenagaratnam, P. M. Khan, P. J. Kingsley, M. B. Kingston, Shanta Kishore, S. Kizhakepat Pisharoth, D. L.' Knights, H. I. Knutzelius, G. W. Kuvelker, Anne G. Lacey,
E. A. Lampel, Barbara V. Latham, I. P. Latto,
Elizabeth M. Lawton, Lillian Ching-Woo Lee, PatEicizabeth M. Lawton, Lillian Ching-Woo Lee, Patricia Lee, Golda Lieberman, C. P. C. Lung, Martin, Helen A. C. Matheson, Isobel M. J Mathias, W. G. A. Maxwell, B. J. Mills, A. D. Moore, A. H. Morris, D. J. Morris, L. A. Mush taq, Z. H. Nagamia, H. M. Nanayakkara, H. M. A. Nazhat, J. M. Newbery, Janet M. Organe, Kokila B. Patel, Y. M. Patel, Mary-Lou Phillips, Oran, B. Radha Rao, F. G. Reader, Ayten Salih, Uran, M. Salni, G. J. H. Sandes, P. C. H. Schofield, D. Shepherdson, R. R. Sheth, H. Shirazi sundram, Louise A. Stephens, M. V. Subhedar, N. K. Tanna, A. Q. Tariq, T. A. Thomas, G H. K. Tippett, $\mathbf{D}$. C. Townsend, P. Vaagenes, Vijayalakshmi, $N$. Voulgaris, Rosalind $M$. Ward, E. J. White, B. L. Whitty,
J. B. Wylie, J. F. Wynters.

\section{ROYAL COLLEGE OF PHYSICIANS AND SURGEONS OF GLASGOW} D.C.H.-W. I. Aderele, M. A. Ahmed, M. M
Ali, Farhat Amin, Z. H. Arastu, M. M. Ben Halim A. Bhattacharyya, Blizabeth M. Bryan, Ann, Fleming, A. Ghosh, S. Hoq, M. K. Hoque S. D. L. Jain, Helen S. Kennedy, M. S. Khan Valparla Manorama, S. R. Mayhew, S. L. Mehra,

\section{New Issues of Specialist Journals}

Obtainable from the Publishing Manager, B.M.A. House, Tavistock Square, London W.C.1.

\section{TH O RA X}

Contents of the fuly issue are as followos

Experimental Mitral Valve Replacement with a Heterograft Aortic Valve in a Rigid Metal Ring. B. Proctor.

A Technique for Complete Replacement of the Ascending Aorta. Hugh Bentall and Antony de Bono

An Annual Cycle in the Ventilatory Capacity of Men with Pneumoconiosis and of Normal Subjects. A Rare Type of Atrial Septal Defect. R. J. M. McCormack, D. Pickering, and I. I. Smith.

Candida Endocarditis after Heart Surgery. N. Conway, M. L. Kothari, Eunice Lockey, and $M$. H.

Yacoub.
Mucoid Impaction of the Bronchi in Relation to Asthma and Plastic Bronchitis. A. D. Morgan and W. Bogomoletz.

Recurrent Spontaneous Pneumothorax Concomitant with Menstruation. Rosemary Davies.

Neurogenic Tumours with an Intrathoracte Localization. W M. Oosterwijk and J. Swierenga.

Ronary Artery Banding in Congenital Heart Disease Associated with Pulmonary Hypertension. J. M. Serum Enzyme Changes after Major Lung Surgery Whth and Without Halothane. A. R. Hunter.

Serum Enzyme Changes after Major Lung Surgery Whb and Without Halothane. A. R. Hunter.

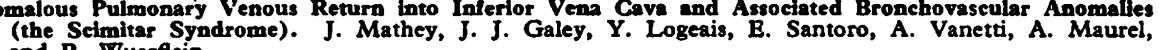
and R. Wuerflein.

I.ong-term Survival of Dogs after Experimental Pulmonary Reimplantation and Staged Contralateral . P. McN. Hill and $K$. M Shaw

The Value of Lung Cancer Detection by Six-monthly Chest Radiographs. G. Z. Brett.

Respiratory Gas Exchange in Patients with Spontaneous Pneumothorax. R. M. Norris, I. G. Jones, and J M. Bishop.

Bndometriosis of the Lung. Tatiana Jelihovsky and A. F. Grant

Heemorrhagic Necrosis of Small Intestine and Acute Pancreatitis lollowing Open-heart Surgery. B. H. Horton, S. K. Murthy, and R. M. E. Seal. Horton, S. K. Murthy, and R. M. E. Seal.
Relationship Between Transpulmonary Artery Distance and Pulmonary Arterial Pressure in Patients with
Chronic Bronchitis. P. Hicken, I. D. Green, and J. M. Bishop.

Volume 23, No. 4. Yearly subscription (6 numbers) £4 4s., abroad £4 $15 s$.

\section{ABSTRACTS OF WORLD MEDICINE}

The July issue (Volume 42 , No. 7 ) is now available. Published monthly. Yearly subscription £6 6s., U.S.A. \$18. Single number 12s. 6d.
Mustahib-ul-Islam, A. O. Ogunmekan, C. S. Steele, Anne D. T. Stephens.

\section{ROYAL COLLEGE OF PHYSICIANS OF IRELAND}

At a special meeting of the College held on 28 June, the President, Professor Alan Thompson, admitted the following to the Licence in Medicine and Obstetrics :

A. Ahmad, G. G. Almeida, A. Asmal, D. J Austin, N. Bagoon, S. Bhowani, A. S. Cassim, Davis, Ann Dawson, J. Essack, S. O. Fagbewesa, R. A. Fahy, A. F. Dinah, Hedy M. Frank, P. D Gry, G. A. Gbadebo, A. C. Gooberdhan, Liuting P. S. Johnson, A. G. Jones, Daljit Kaur, M. H. Y Khadiaroo, D. Lintern, P. K. Madon, B. C. Madu, C. B. Malde, V. R. Mooneeram, E. Moosajec, Sheila McCluskey, i. R. Naidoo, Mary P Kwee Lim, S.j. O'Sullivan, D. Padayachee, V. K. Patel, N. P. Pillay, S, W. Pillay, S. Persad, J. D. Price, Sarah C. F. Ro'gers, A. J.' Rynne, M. G. P Salter, E. R. Samuels, S. Selvasothy, P. B. Sharma an Chin Chai, $M$. Bentley-Taylor, V. S Vaithilingam, P. J. Walls.

\section{Correction}

In some early copies of the B.M.F. the first sentence of the third paragraph of the letter "Twentieth Anniversary" (13 July, p. 125) was incorrectly printed. It should have read: "Once again, with two exceptions, the doctors selected to present the profession's case were completely overwhelmed. They appeared to be on the screen merely to allow the Minister to underline his arguments."

\section{Notice to Authors}

When original articles and letters for publicaion are not submitted exclusively to the British Medical fournal this must be stated.

Correspondence on editorial business should be addressed to the Editor, British Medical fournal, B.M. House, Tavistock Square, London W.C.1, Telephone: 01-387 4499. Telegrams: Aitiology, London W.C.I.

Authors wanting reprints of their articles should notify the Publishing Manager, B.M.A House, Tavistock Square, W.C.1, on receipt of proofs.

\section{Subscriptions}

Members' subscriptions should be sent to the Secretary of the British Medical Association, B.M.A. House, London, or to the Scottish Secretary, B.M.A. Scottish Office, Drumsheugh Gardens, Edinburgh.

Doctors who are not members of the B.M.A can subscribe to the B.M.F. The rates for doctors resident in the United Kingdom and abroad are given on the first page of the classified advertisements. These include the rates for the Australian edition and the Nort" American "Air Express," which are available to both members and non-members of the B.M.A

\section{Classified Advertisements}

Doctors Abroad.-Copies of the appointment vacancies advertised in the B.M.F. can be sent by airmail on request. The minimum cost is 3s. per week, for which copies of vacancies in up to five sections of the classified advertisements will be sent. The cost of each further section after five is 1s. Orders for specific grades in any section cannot be accepted. Payments should be enclosed with the order.

Details of rates, etc., for classified advertisements appear on the first page of the classified section. 